\title{
Status of Critical Mineral Concentration in Soil and Blood Serum of Sheep, in the Case of Southern Ethiopia
}

\author{
Muluken Zeleke \\ Bonga Agricultural Research Center, Bonga, Ethiopia.
}

\begin{abstract}
How to cite this paper: Muluken Zeleke. (2021) Status of Critical Mineral Concentration in Soil and Blood Serum of Sheep, in the Case of Southern Ethiopia. International Journal of the Science of Food and Agriculture, 5(1), 183-188. DOI: 10.26855/ijfsa.2021.03.024

Received: February 3, 2021

Accepted: March 2, 2021

Published: March 25, 2021

*Corresponding author: Muluken Zeleke, Bonga Agricultural Research Center, Bonga, Ethiopia.

Email: Mulukenzeleke2017@gmail.com
\end{abstract}

\begin{abstract}
The mineral soil samples were collected from the study site from a depth of 30 $\mathrm{cm}$ to analyze for the status of mineral content in soil commonly supplemented as mineral and serum of sheep. The result revealed that the mean content of macro (\%) and trace (ppm) elements in two different type were Ca $(0.41,0.51)$; $\mathrm{Mg}$ (0.20, 0.16); K (0.31, 0.40); Na (3.01, 4.86); P (0.02, 0.04); Fe (92.24, 87.09); Mn $(165,120)$; Zn $(12.16,17.56)$ and $\mathrm{Cu}(4.52,5.06)$, respectively. A high content of Na $(\mathrm{P}<0.01)$ and $\mathrm{Mn}(\mathrm{P}<0.001)$ was observed in makaduwa mineral soil. The concentration of $\mathrm{Ca}$ and $\mathrm{Na}$ in makaduwa was at the level to meet the $\mathrm{Ca}$ and $\mathrm{Mg}$ requirements of ruminants. The $\mathrm{Na}, \mathrm{Fe}$, and $\mathrm{Mn}$ contents in both bole and makaduwa are above the requirement level, whereas $\mathrm{Zn}, \mathrm{P}$, and $\mathrm{Cu}$ contents are below the requirement. Serum mineral concentration is within the normal range for Ca, $\mathrm{Mg}, \mathrm{Cu}$, and $\mathrm{Zn}$ for those fed mineral soil.
\end{abstract}

\section{Keywords}

Mineral Soil, Mineral Requirement, Serum Mineral, Sheep

\section{Introduction}

In Ethiopia, the livestock sector has been contributing considerable share to the national economy of the country, for instance through export commodities of live animals, hides, and skin to earn foreign exchange to the country. However, livestock productivity is very low and lags behind the growth of the human population leading to a net decline in per capita consumption of livestock products [1].

The major feed resources for ruminants in Ethiopia are green forages from natural pasture, crop residues and feed grain/other concentrates [2]. Among these feed resources, the expansion of cropping area as a result of human population pressure makes crop residues to be very important, especially during the dry season [3]. Residues of cereal and pulses accounts for about $26 \%$ of total feed utilized and ranked second to grazing in the mixed crop-livestock production system of Ethiopia [4].

Large numbers of livestock in many parts of the world consume diets that do not meet exacting requirements [5]. Deficiency of minerals in under grazing and grazing plus concentrate supplementation has been reported [6]. During the dry season when the available forage is low in quantity, quality and mineral contents, what usually occurs is the loss of live weight, low birth weights, lowered resistance to disease and reduced animal performance [7] also reported that overgrazed pastures in Ethiopia are deficient in Calcium (Ca), Phosphorus (P), Sodium (Na), Zinc (Zn), Copper (Cu), cobalt (Co), sulfur (S) and selenium (Se), but their Iron (Fe) and Magnesium (Mn) levels are too high. Significant differences of $\mathrm{CP}, \mathrm{Ca}, \mathrm{P}, \mathrm{K}, \mathrm{Mg}, \mathrm{S}, \mathrm{Na}, \mathrm{Zn}, \mathrm{Se}, \mathrm{Mn}, \mathrm{Cu}$, and Mo concentrations between shrub and grass species were documented with a clear nutritional advantage for sheep having access to shrubs in the winter [8].

Mineral deficiencies are considered to be one of the nutritional constraints to animal productivity. Local mineral deficiencies and imbalances are likely to become more apparent and more critical [8]. Mineral imbalances (deficiencies or 
excesses) in soils and forages have long been held responsible for low production and reproductive problems among grazing ruminants in the tropics. Poor body conditions, slow live weight gain, low fertility, and high mortality are normally observed in mineral-deficient animals [8].

Feeds, mineral soils and water are the major mineral sources for sheep in Ethiopia [7]. Bole (an Ethiopian name for soil lick) is one of the widely spread resources, cheap and well licked by animals once they were accustomed to it. Makadwa is also a type of lick soil used in Southern part of Ethiopia. The feeding strategies are either by trekking animals to natural mineral soil areas or by bringing the mineral soil to animals holding pen. In some areas where farmers located far away from natural mineral soil area are purchasing it from local markets. According to Tolers [7] in some parts of Ethiopia, supplementation with multi-nutrient mineral blocks and local mineral soils may provide an adequate or even excess amount of essential minerals.

Mineral supplementation plays a vital role in increasing the nutritive value of low-quality roughages and crop-products in developing countries [8]. The supplementary need for minerals and concentrate mixture to sheep of various ages under grazing has also been advocated [6]. The animals must be supplied with a diet that is palatable and non-toxic and which contains the required minerals, as well as other nutrients, in adequate amounts, proper proportion, and available forms [9]. Thus, it is necessary to provide supplementary minerals to promote efficient and profitable livestock production in warm climate regions.

Evidence on the concentration of critical minerals in the soil and serum is a critical pre-requisite for the intervention of the mineral deficiencies or toxicities of sheep diets ration formulation and feeding strategies. Although sheep are economically important in the region, little has been done on the mineral status of soil and sheep. Therefore, this study was designed to assess some critical mineral elements concentration in the soil and serum of sheep.

\section{Methods}

\subsection{Design and Sample}

The study was conducted in the southern region of Ethiopia located at an altitude of 1,100 to 2,300 meters above sea level and $6^{\circ} 40^{\prime} \mathrm{N}$ latitude and $37^{\circ} 50^{\prime} \mathrm{E}$ longitude. The Mean annual rainfall and temperature of the study area are $1,123.15 \mathrm{~mm}$ and $22.0^{\circ} \mathrm{C}$, respectively. The district has a total area of 86,646 hectares (ha) which is $70 \%$ of the lowland and $30 \%$ of midland [10].

The mineral soil samples were taken directly from the depressions where the animals lick/eat the soil. Before sampling, the top ten-centimeter layer was scraped and discarded in case of contamination. An individual mineral soil sample was collected in a plastic collection bag using an auger to the depth of $20 \mathrm{~cm}$ from 12 different depressions which fall approximately in the radius of $40 \mathrm{~m}$. The samples from closer depressions were mixed and a total of two composite soil samples were collected for the analysis of both critical mineral concentrations. After collection, mineral soil samples were allowed to dry in the air. Then the samples were pounded with clean mortar and pestle. The ground samples were sieved to pass through a two mm sieve screen and stored in plastic bags until analysis [11].

Blood samples were collected from all experimental 50 sheep by using $10 \mathrm{ml}$ sodium heparinized test tubes by puncturing the jugular vein. The collected blood samples were immediately centrifuged to separate plasma from serum. Then separated serum will be kept in cold storage $\left(-20^{\circ} \mathrm{C}\right)$ until for mineral analysis. The mineral concentrations (Ca, Mg, Fe, $\mathrm{Mn}, \mathrm{Zn}, \mathrm{Fe}$, and $\mathrm{Cu}$ ) in serum were analyzed by using an atomic absorption spectrophotometry (Model 210 VGP, USA). Sodium and $\mathrm{K}$ were determined by using flame photometry and $\mathrm{P}$ was determined by using the photometric method according to [12].

\subsection{Analytical Procedures}

The soil samples were analyzed for both physical properties and mineral concentration. Soil texture was determined by the hydrometer method after destroying OM and disposing of the soil with a dispersing agent known as sodium hexametaphosphate that oxidizes the OM present as a cementing agent to separate the soil mass into its primary particles. Soil $\mathrm{pH}$ was measured by using a $\mathrm{pH}$ meter in a 1:2.5 soil: water ratio. Soil organic carbon was determined following the wet digestion by Walkly and Black oxidation method. The percent soil OM was calculated by multiplying the percent organic carbon by a factor of 1.724 , following the standard procedure that $\mathrm{OM}$ is composed of $58 \%$ carbon. $\mathrm{Ca}, \mathrm{Mg}, \mathrm{Fe}, \mathrm{Mn}, \mathrm{Zn}$, and Cu were determined by atomic absorption spectrometer. Sodium and Potassium were analyzed by using flame photometrically. Available phosphorus was determined following the standard Olsen extraction method [11].

\subsection{Statistical Analysis}

The data obtained on mineral concentration was subjected to analysis of variance based on the model for completely randomized design in factorial arrangement using the General Linear Model (GLM) procedures of the Statistical Analy- 
sis System. The statistical differences between means were estimated by the LSD test.

\section{Results and Discussion}

\subsection{Mineral concentration of soil}

According to the critical level established for sheep, Ca content of bole $(0.41 \%)$ and makaduwa $(0.51 \%)$ in the present study can meet the requirement from 1.4 to $7 \mathrm{~g} \mathrm{Kg}-1$ set by AFRC (2007) [12], from 0.20 to $0.82 \%$ set by NRC (1985) [13] and $0.37 \%$ set by AFRC. The Ca content of soil lick is comparable with soil lick from Zeway (0.35\%) and Medacho (0.5\%) [14], however, it is lower than soil lick from lake Shala (1.7\%), Did Harra (1.7\%), Negele (1.52\%) and Nile valley (2.21\%) [14]. Dissimilarity observed in values of some mineral element is normal as soil varies from site to site depending on the parent material soil licks were derived and also on the soil formation process [15].

Concentration of $\mathrm{Mg}$ in bole (0.2\%) and makaduwa (0.16\%), according to the stipulated critical level of $\mathrm{Mg}$ for Sheep from 0.12 to $0.18 \%$ [16], bole and makaduwa analyzed in this study can satisfy the recommended level of $\mathrm{Mg}$ for sheep. This result comparable with the Mg concentration of soil lick from Lake Zeway (0.2\%) [15] and the report of Temesgen [17] 0.18\% for soil lick from Jijiga in the wet season. However, lower than Lake Shala (1.5\%), Nile Valley (0.99\%) [15].

The Na concentration of bole (3.01\%) and makaduwa (4.86\%) are above the upper limit of the requirement recommended level from 0.07 to $0.1 \%$ set by [16] and from 0.09 to $0.18 \%$ set by [17]. In agreement with the Na value of the current study, mineral soils can serve as a universal role of supplementing diets with Na [19]. Similarly, Mohamed [20] reported that mineral lick soil can adequately fulfill Na need for cattle and sheep.

The concentration of $\mathrm{K}$ in bole $(0.31 \%)$ and makaduwa $(0.40 \%)$ is below the recommended level of the requirement by [21], meaning that, dietary $\mathrm{K}$ levels should not fall below the critical levels of $0.5 \%-0.8 \%$. Based on the suggested requirement for $\mathrm{K}$ for ruminants, the analyzed mineral soils cannot supplement $\mathrm{K}$ for the licking sheep in the study areas. In a similar study, [15] and [20] also reported that mineral soil licks are not capable of satisfying the K requirement of cattle and sheep, respectively. Fikire [22] reported that mineral soil licks contained an adequate level of potassium for ruminants. This could be due to variations in the parent materials where the mineral soil licks are derived and also on the soil formation process [23].

The mineral soil bole $(0.02 \%)$ and makaduwa $(0.04 \%)$ used in this experiment could not be used as the source of $\mathrm{P}$ to meet $\mathrm{P}$ requirements for a sheep according to recommend level from 0.26 to $0.28 \%$ set by [13], and from 0.2 to 0.29 set by NRC [14]. The current finding is similar to the report of [15] lick soil from Lake Shala (0.02\%), Lake Zeway (0.02\%), and Medacho (0.01\%). The same author similarly suggested that P concentration of maqaduwa from Lake Abaya is $0.05 \%$. This is also in agreement with the works of [15], [20], [22] and [23], and [18], they reported that P content of lick soil is lower than the recommended level.

In this study, the Cu concentration obtained for bole (4.52 ppm) and makaduwa (5.06 ppm) are close to the value reported by [18] who found 0.82 to $4.42 \mathrm{ppm} \mathrm{Cu}$ in mineral soil from different location of Jijiga woreda. From the present result, $\mathrm{Cu}$ in mineral soil was deficient to supply the critical level of 7 to $11 \mathrm{ppm}$ suggested by [21] and [17]. The deficiency of $\mathrm{Cu}$ was also reported [18]. However, the $\mathrm{Cu}$ content reported in the present study is higher than the value reported [23] where $\mathrm{Cu}$ content ranged from 0.28 to $2.22 \mathrm{ppm}$.

The concentration of Fe in bole and Makaduwa was $92.24 \mathrm{ppm}$ and $87.09 \mathrm{ppm}$, respectively. Compared to the stipulated level [13] and from 30 to 50 ppm of NARC [17], Fe was found to be adequate to supplement sheep in the study area. The current finding is comparable with the Fe value reported by [18], [20], [22] and [18] in which they reported that mineral soil lick contained Fe from acceptable level to too excess than the ruminant requirement.

The Mn value in bole and makaduwa were $165 \mathrm{ppm}$ and $120 \mathrm{ppm}$, respectively. According to NARC, Mn for sheep requirement ranges from 20 to $40 \mathrm{ppm}$. A study on the Mn requirement of growing sheep [24] showed that $13 \mathrm{ppm}$ was adequate for live weight gain. In agreement with the current study, [20], [22] and [18] reported that mineral soils contained above the acceptable level of Mn for ruminants. In contrast, [15] and [25] reported Mn deficiency in mineral lick soil.

The concentration of $\mathrm{Zn}$ in bole (12.16 ppm) and makaduwa (17.56ppm) could not meet the stipulated requirement of sheep from 20 to $30 \mathrm{ppm}$ [17]. This finding is similar to the report of [15], [23], and [18] who reported that lick soils are deficient in Zn concentration to supplement sheep.

\subsection{Serum Mineral Concentration}

There is no significant difference $(\mathrm{P}>0.001)$ between bole $(115.8 \mathrm{ppm})$ and makaduwa (116.9 ppm). According to [25], healthy sheep can contain from 90 to $120 \mathrm{ppm}$ of Ca in serum. The current study is also agreed with the report of Kaneko [26] normal level of serum Ca in healthy lamb from 11.9 to $12.4 \mathrm{mg} / \mathrm{dl}$ (119 to $124 \mathrm{ppm}$ ) and Puls [27] from 90 to130 ppm. The finding in this study is also nearer to the value of Latimer [28], who reported that the normal range of Ca for in serum of sheep is 9.3 to $11.7 \mathrm{mg} / \mathrm{dL}$ (93 to $117 \mathrm{ppm}$ ). The concentration of $\mathrm{Ca}$ in all treatment groups is below 
moderate hypercalcium level from 120 to 150 ppm set by Littledike [29] which causes calcifications of soft tissues and depress feed intake. In contrast with the present study, Sisay [23] reported that the Ca level of serum ranges from 231.00ppm to $243.50 \mathrm{ppm}$ in sheep which fed different mineral soil sources. The variation in serum Ca concentration between animals might be associated with endocrine secretions [25].

The $\mathrm{P}$ concentration in the serum in bole $(33.4 \mathrm{ppm})$, and makaduwa $(35.0 \mathrm{ppm})$ is significantly varied $(\mathrm{P}<0.001)$ between treatment groups. These others are below the normal range of $\mathrm{P}$ in the serum of sheep ranges from $40 \mathrm{ppm}$ to $80 \mathrm{ppm}$ set by Latimer [28]. This could be due to the low P concentration of mineral soil supplements. For grazing livestock, the more devastating economic result of $\mathrm{P}$ deficiency is reproductive failure [30]. Thus, deficiency of $\mathrm{P}$ in mineral soil supplements and low in the serum of camels could be a good indicator of deficiency of $\mathrm{P}$ in the study area.

The concentration of $\mathrm{Mg}$ in the serum of sheep for bole (41.1ppm), and makaduwa (33.0ppm). The Mg concentration recorded in bole $(41.1 \mathrm{ppm})$ was significantly higher $(\mathrm{P}<0.01)$ than the other. Analysis of serum samples from all treatment sheep indicated an adequate amount of $\mathrm{Mg}$ in the serum. This could be due to higher $\mathrm{Mg}$ concentration in bole than other treatment feeds. This finding is in close with Sisay [23] who reported that serum Mg concentration of sheep which feed different mineral soils range from 25.70 to $41.8 \mathrm{ppm}$. The value of the current finding is above the critical level from 10 to $20 \mathrm{ppm}$ for sheep [21], normal range from 20 to $27 \mathrm{ppm}$ set by [28] and from 19 to $30 \mathrm{ppm}$ set by [27]. However, the concentration of $\mathrm{Mg}$ in the current study is below toxic level (>60ppm) which causes diarrhea in sheep [17].

Potassium concentration (ppm) bole (143.0) and makaduwa (142.1). The results of serum K concentration are below the normal range suggested by Jackson [31], from 152 to 210.6 ppm. This could be due to low K concentration in concentrates and mineral soils. In agreement [21], concentrate feed contains low K (0.5\%) compared to the requirement and low serum $\mathrm{K}$ caused by the deficiency of $\mathrm{K}$ concentration in the feed.

The Na concentration (ppm) of bole, and makaduwa is 2,766.2, and 2,743.4 respectively. The concentration was found to be significantly $(\mathrm{P}<0.001)$ different among treatments where the highest and lowest serum Na concentrations were recorded in bole (2,766.2). The Na concentration in the group is above the range from 1,420ppm to 1,600ppm set by Latimer [26]. The results of the current study are greater than the report of [23] where serum Na is 2,023 ppm in sheep and, lower than the report of [31], 3,266 ppm to 3,450 ppm. The variation could be due to bioavailability and interaction of $\mathrm{Na}$ in feeds used [32] and genetic differences of animals [21].

The $\mathrm{Cu}$ concentration $(\mathrm{ppm})$ of bole, and makaduwa 0.9 , and 0.8 respectively. The higher $(\mathrm{P}<0.001)$ serum $\mathrm{Cu}$ concentration $(1.1 \mathrm{ppm})$ was determined for sheep who received bole. The treatments which fed bole $(0.9 \mathrm{ppm})$ and makaduwa $(0.8 \mathrm{ppm})$ were significantly higher $(\mathrm{P}<0.001)$ than other areas $(0.5 \mathrm{ppm})$. The serum concentrations reflect the dietary $\mathrm{Cu}$ status, although the normal range is wide. For instance, for sheep normal range is between 0.6 and $1.5 \mathrm{ppm}$ [33]. Comparing to the critical deficiency, serum values for sheep suggested [21] is $0.65 \mathrm{ppm}$ for $\mathrm{Cu}$, the value in the current study was above the critical standard value and below toxicity level $1.2 \mathrm{ppm}$ set by the same author.

The concentration of Fe in the serum of sheep in bole (4.13), and makaduwa (2.73). As indicated Fe concentration in serum of sheep ranged from $2.61 \mathrm{ppm}$ in bole to 4.13ppm. The group which fed makaduwa had a significantly higher $(\mathrm{P}<0.001)$ value than the animals which fed bole, this could be due to higher $\mathrm{Mg}$ concentration in bole interfere with $\mathrm{Fe}$ absorption. Similarly [34] reported that when feeding a diet of sheep which contains 140-200 ppm Mg was significantly depressed serum Fe concentration. The mean serum Fe concentration observed in this study is comparable with the report [23]. The current finding is above the normal range from 0.7 to $2.0 \mathrm{ppm}$ set by Pulse (1994). This could be due to excessive concentration of Fe in mineral soil supplements when compared with the recommended requirement of sheep.

Manganese serum concentration (ppm) of the current study was 0.06 , and 0.12 bole and, makaduwa respectively. It has indicated in the present study that T4 had a significantly higher $(\mathrm{P}<0.001)$ serum Mn concentration than another treatment group. This finding is comparable with the report of Sisay [23], who stated that after supplementation of different mineral soil Mn concentrations in serum of sheep range from 0.06 to $0.09 \mathrm{ppm}$. According to Puls [27], Mn concentrations bole are within the adequate recommended range from 0.006 to $0.07 \mathrm{ppm}$. However, Mn concentration in BOLE and T4 above the adequate range, this could be due to higher Mn concentration bole (167ppm) and CMM (840 $\mathrm{ppm})$. The increments of dietary Mn concentration from 123-147 ppm increases Mn concentration by 25\% in tissues of animals [34].

The concentration of $\mathrm{Zn}(\mathrm{ppm})$ in the serum of bole, and makaduwa T4 is 1.08, and 1.15 respectively. The serum Zinc level of T4 (1.68) was significantly higher $(\mathrm{P}<0.001)$ than other groups. Treatment which fed makaduwa $(1.15$ $\mathrm{ppm}$ ) is significantly higher than bole (1.08). Sheep supplemented with commercial mineral mix had high Zn concentration in blood than sheep supplemented with mineral soil. The current finding is within the range from 0.55 to $1.2 \mathrm{ppm}$ [35]. The serum Zn concentration found in the present study is below the critical level of 2ppm suggested by McDowell [20]. 
Table 1. Serum mineral concentration (ppm) of sheep fed mineral soils

\begin{tabular}{ccccc}
\hline & & Treatments, Mean & & \\
Parameter & bole & makaduwa & $\mathrm{t}$ & $* * *$ \\
\hline $\mathrm{Ca}$ & $5.8 \mathrm{~b}$ & $116.9 \mathrm{~b}$ & 3.53 & $* * *$ \\
$\mathrm{P}$ & $33.4 \mathrm{c}$ & $35.0 \mathrm{~b}$ & 1.70 & $* * *$ \\
$\mathrm{Mg}$ & $41.1 \mathrm{a}$ & $33.0 \mathrm{~b}$ & 1.06 & $* * *$ \\
$\mathrm{~K}$ & $143.0 \mathrm{~b}$ & $142.1 \mathrm{c}$ & 4.03 & $* * *$ \\
$\mathrm{Na}$ & $2766.2 \mathrm{a}$ & $2743.4 \mathrm{~b}$ & 6.23 & $* * *$ \\
$\mathrm{Cu}$ & $0.9 \mathrm{~b}$ & $0.8 \mathrm{c}$ & 0.87 & $* * *$ \\
$\mathrm{Fe}$ & $4.13 \mathrm{a}$ & $2.73 \mathrm{c}$ & 0.12 & $* * *$ \\
$\mathrm{Mn}$ & $0.06 \mathrm{c}$ & $0.12 \mathrm{~b}$ & 0.05 & $* * *$ \\
$\mathrm{Zn}$ & $1.08 \mathrm{c}$ & $1.15 \mathrm{~b}$ & 0.58 & $* 5$ \\
\hline
\end{tabular}

\section{Conclusion}

This study identified the concentration of $\mathrm{Ca}$ and $\mathrm{Na}$ in makaduwa was at the level to meet the Ca and Na requirement of ruminants. The $\mathrm{Na}, \mathrm{Fe}$, and $\mathrm{Mn}$ contents in both bole and makaduwa are above the requirement level, whereas $\mathrm{Zn}, \mathrm{P}$, and $\mathrm{Cu}$ contents are below the requirement. It is recommended that a strategic mineral survey which should include analysis of soil, water, grass, and animal tissue must be undertaken in the different areas of the region to detect mineral imbalances for proper mineral supplementation. Serum mineral concentration is within the normal range for $\mathrm{Ca}$, $\mathrm{Mg}, \mathrm{Na}, \mathrm{Cu}, \mathrm{Fe}, \mathrm{Mn}$, and $\mathrm{Zn}$ are meet normal standard range for those fed mineral supplements than the control group. It is recommended filling the gap by supplementation strategies of feed.

\section{References}

[1] Shawel Bertu and Kawshima, H. (2009). Pattern and determinants of meat consumption in urban and rural Ethiopia. Department of global agriculture, Graduate School of Agriculture and Life Sciences, the University of Tokyo, p. 216.

[2] Tingley, J. P., Low, K. E. (2021). Combined whole cell wall analysis and streamlined in silico carbohydrate-active enzyme discovery to improve biocatalytic conversion of agricultural crop residues. Biotechnol Biofuels.

[3] Daniel Kaftasa. (1998). Role of crop residues as livestock feed in Ethiopia highlands. Pp. 430-439. In: B.H. Dzowela (eds.). Africa Forage Plant Genetics Resource, Evaluation, of Forage Germplasm and Extensive Livestock Production System. Proceeding of the Third PANESA workshop held 27-30 April, 1987 in Arusha, Tanzania.

[4] CSA (Central Statistical Agency). (2010). An agricultural sample survey of 2004/05. Report on area and production of winter season crop for private peasant holdings. Vol. 5: Bulletin.

[5] McDowell, L. R., Conard, J. H., Ellis, G. L., and Loosli, J. K. (1993). Minerals for Grazing Ruminants in Tropical Regions. Department of Animal Science Department, Center for Tropical Agriculture. The University of Florida, Gainesville, Florida.

[6] Samanta, A. and Samanta, G. (2002). Mineral profile of different feed and fodders and their effect on plasma profile in ruminants of West Bengal. Indian Journal of Animal Nutrition, 19: 278-281.

[7] Ademi, A, Bernhoft, A., Govasmark, E., Bytyqi, H., Sivertsen, T., Singh, B. R. (2017). Selenium and other mineral concentrations in feed and sheep's blood in Kosovo. Transl Anim Sci 1: 97-107. Alexis A. M. Julian, John D. 2020. Mineral element concentrations of common grass and shrub species on sheep winter range in Wyoming: insights for mineral supplementation strategies, Translational Animal Science, Volume 4, Issue Supplement.

[8] HBDA. (2015). Humbo Burea of agricultural development, unpublished report.

[9] Baruah, T. C. and Barthakur, H. P. (1997). A text book of soil analysis. Vikas publishing house pvt plt. Masjid Road, Jangpura, New Delhi, India. Pp. 334-345.

[10] Azarzar omari. (2020). Blood mineral status of suffolk sheep influenced by season, sheep lines and geographical location. Lithuanian University of Health Sciences Veterinary Academy.

[11] AFRC (Australian Feed Research Council). (2007). Nutrient Requirements of Domestic Ruminant. CSIRO publishing, Australia.

[12] NRC (National Research Council). (2005). Mineral Tolerance of Animal. $2^{\text {nd }}$ ed. National Academy of Sciences, Washington, D.C. 
[13] Kabaija, E. and Little, D. (1988). Nutritive quality of forage in Ethiopia with particular reference to mineral elements. Pp. 423-427. Proceeding of the $3^{\text {rd }}$ workshop held at the international conference center, Arusha, Tanzania on pasture network for Eastern and Southern Africa (panesa). ILCA, Addis Ababa.

[14] Jenifer Pereja, Monica B. (2020). Effect of mineral supplementation on lead bioavailability and toxicity biomarkers in sheep exposed to mining pollution. Elsiver.

[15] NRC (National Research Council). (1985). Nutrient Requirements of Sheep. National Academy of Sciences, Washington, D.C. P. 75.

[16] Temesgen Desalegn. (2012). Assessment of some critical mineral elements in feed, Non-conventional mineral supplements and serum of Camels (camelus dromedarius) in Jijiga woreda. An Msc Thesis Submitted to School of Graduate Study of Haramaya University.

[17] Mincher, B. J. (2008). Some aspects of geophagia in Wyoming bighorn sheep (Oviscanadensis). Wildlife Research, 54: 193-198.

[18] Mohammed, Y. Kurtu, Mugerawa, E. M., and Edo, D. (1989). Effect of supplementation with lake soil on the growth of Arsi sheep.

[19] McDowell, L. R. (2003). Minerals in Animal and Human Nutrition, 2nd ed. Amsterdam: Elsevier.

[20] Fikre, A. (1990). The mineral composition and effect of bole local natural lick supplementation on feed intake, digestibility and weight gain of Black Head Ogaden sheep. MSc Thesis, Alemaya University of Agriculture. Alemaya, p. 165.

[21] Sisay Tilahun, Vijchulata, P., Chairatanayuth, P. and Swasdiphanich, S. (2007). Effects of Natural Mineral Soils on Body Weight and Liver Minerals of Black Head Somali Sheep in Ethiopia.

[22] Masters, D. G., Paynter, D. I., Briegel, J., Baker, S. K., and Purser, D. B. (1988). Influence of manganese intake on body, wool and testicular growth of young rams and on the concentration of manganese and the activity of manganese enzymes in tissues. Australian Journal of Agricultural Research, 39: 517-524.

[23] Underwood, E. J. and Suttle, N. F. (1999). The Mineral Nutrition of Livestock ( $3^{\text {rd }}$ ed). CAB international, UK.

[24] Kaneko, J. J. (1989). Clinical biochemistry of domestic animals. 4th ed. Academic Press, pp. 146-159, 612-647.

[25] Puls, R. (1994). Mineral Levels in Animal health. Diagnostic Data. Sherpa International. Canada.

[26] Latimer, K. S., Mahaffey, E. A., Prasse, K. W. (2003). Duncan and Prasse's Veterinary Laboratory Medicine: Clinical Pathology. 4th ed., Iowa, Iowa State Press, pp. 173-174.

[27] Littledike, E. T., Glazier, D., and Cook, H. M. (1976). Electrocardiographic changes after induced hypercalcemia and hypocalcemia in cattle. Animal Journal Veterinary Research, 137: 383-388.

[28] McDowell, L.R. and Valle, G. C. (2000). Major minerals in forages. Pp. 373-375. In: D.I. Givens, E. Owen, R. F. E. Axford and H. M. Omed. Forage Evaluation in ruminants Nutrition. Biddles Ltd., Guildford and King’s Lynn, UK.

[29] Jackson, G. G. and Peter, D. C. (2002). Clinical Examination of Farm Animals. Blackwell Science Ltd.

[30] Sharma, L. C., P. S. Yadav, A. B. Mandal. and K. R. Sunaria. (2004). Mineral Status of some Vital Organ of Lambs as Influenced by their Dietary Levels. Animal Nutrition and Feed Technology, 2: 151-160.

[31] CMN. (1973). Treating Mineral Disorders in Dairy Cattle. Committee on Mineral Nutrition. Center for Agriculture Publishing and Documentation, Wageningen, Netherlands, pp. 116-118.

[32] Grace, N. D. and Lee, J. (1990). Effect of Co, Cu, Fe, Mn, Mo, Se and Zn supplementation on the elemental content of soft tissues and bone in sheep grazing ryegrass/white clover pasture. New Zealand Journal of Agricultural Research, 33: 635-647.

[33] Healy, W. B. (1974). Ingested soil as a source of elements to grazing, pp. 448-450. In Trace Element Metabolism in Animals-2. University Park Press, Baltimore. 